\title{
Methodological problems of research the penitentiary institution in the context of the public trust
}

\section{Metodologiczne problemy badania instytucji penitencjarnych w kontekście zaufania społecznego}

\author{
Andrzej Borowski \\ Katedra Socjologii i Pracy Socjalnej, Wydział Edukacyjno-Filozoficzny, \\ Akademia Pomorska w Słupsku, ul. Westerplatte 64, 76-200 Słupsk, Poland \\ E-mail address: aubor@poczta.onet.pl
}

\begin{abstract}
The article treat about functioning of penitentiary institutions in the context of the paradigm of total institutions, the author is analysing current methodological arrangements in examining the penitentiary institutions /P. Moczydłowski, M. Ciosek. H. Machel, M. Kamiński/. Next he is presenting own methodological proposals concerning research penitentiary institutions.
\end{abstract}

Keywords: total institution; public trust; penitentiary institution; insularity

\section{STRESZCZENIE}

Artykuł traktuje o funkcjonowaniu instytucji penitencjarnych w kontekście paradygmatu instytucji totalnych, autor analizuje dotychczasowe ustalenia metodologiczne w zakresie badania instytucji penitencjarnych /P. Moczydłowski, M. Ciosek. H. Machel, M. Kamiński/. Następnie prezentuje własne propozycje metodologiczne dotyczący badania instytucji penitencjarnych.

Stowa kluczowe: instytucja totalna, zaufanie społeczne, instytucja penitencjarna, izolacyjność.

\section{WPROWADZENIE W PROBLEMATYKE ZAUFANIA SPOLECZNEGO W INSTYTUCJACH TOTALNYCH}

Zaufanie społeczne związane jest ze zjawiskiem zmiany społecznej, charakterystycznej dla okresów rewolucji politycznych i kulturowych. Jak zauważa P. Sztompka:

"(...) nagłemu poszerzeniu ulega sfera niepewności, ryzyka i zagrożeń, zwiększa się nieprzejrzystość struktur i organizacji (...) Wszystko to podważa poczucie bezpieczeństwa egzystencjalnego, porzadku społecznego, a w efekcie rodzi kryzys zaufania, zarówno horyzontalnego - do innych, jak $i$ wertykalnego - do instytucji publicznych,

$$
\text { prowadzac do kultury cynizmu." [1]. }
$$


„Kultura cynizmu”, jak wyjaśnia Sztompka [2] to inaczej „,kultura nieufności”, a więc

"rozpowszechniona i uogólniona podejrzliwość w stosunku do osób i instytucji, nakazujaca

nieustannie monitorować i kontrolować ich działania $w$ obawie przed oszustwami, nadużyciami, kłamstwami, nierzetelnościa, spiskami i konspiracją". [3].

E. Goffman rozróżniając poszczególne instytucje bierze pod uwagę zróżnicowany stopień absorbowania członków danej instytucji i podporządkowania jej celom.

Istotę instytucji totalnej autor tej teorii określa następująco:

" podstawowy układ społeczny we wspótczesnym społeczeństwie polega na tym, że jednostka dąży do tego by spać, bawić się i pracować w różnych miejscach z różnymi uczestnikami, gdzie wystepuja zróżnicowane rodzaje władzy i nie ma wszechogarniajacego racjonalnego planu. Główna cechą instytucji totalnej jest załamanie się barier oddzielających zazwyczaj te trzy sfery życia".

Według E. Goffmana w społeczeństwie występują rozmaite instytucje totalne, które można podzielić na pięć grup, z których trzecia kategoria koncentruje się na instytucjach chroniących społeczeństwo przed aktualnymi i potencjalnymi przestępcami i wrogami/ więzienia, zakłady poprawcze, obozy jenieckie i koncentracyjne [4].

M. Foucault analizuje instytucje penitencjarne jako narzędzie wpływu społeczeństwa na indywidualne sposoby postępowania i ujmowania świata społecznego. Celem instytucji penitencjarnych jest według niego:

dyscyplinowanie członków społeczeństwa przez narzucenie im wzorów typologizowania /typizacji/ oraz podejmowanie działań traktowanych przez społeczeństwo jako „,normalne”,

nie burzace istniejacego i akceptowanego porzadku. Dyscyplinowanie odbywa się przez

kształtowanie odpowiednich praktyk oraz stała wzajemna obserwację i nadzór. [5].

C. Davies przedstawił zbiorczą przegląd literatury odnośnie instytucji totalnych. Daje się zauważyć, że E. Goffman używa tego terminu sposób luźny. W szczególności, C. Davies sugeruje że goffmanowska analiza byłaby bardziej jasna, gdyby odniósł się on do instytucji totalnej jako organizacji, kierując się trzema kluczowymi zmiennymi:

1. miejscem pobytu pensjonariuszy

2. istnieniem różnych formalnych uzasadnień funkcjonowania instytucji totalnych

3. zróżnicowanymi trybami formowania postawy uległości podwładnych, używanymi przez personel instytucji totalnych [6].

\section{POLSKIE BADANIA NAD INSTYTUCJAMI TOTALNYMI A ZAUFANIE SPOLECZNE}

P. Moczydłowski prowadząc w latach 80-tych XX w. badania w polskich instytucjach penitencjarnych zauważył, istnienie zjawiska unikania wiedzy negatywnej. Funkcjonowanie jednostek penitencjarnych jest mocno sformalizowane, oparte na przepisach prawa.

Przypadki niewłaściwego/nieprofesjonalnego/ działania personelu więziennego w trakcie prowadzonych przez autora badań w wyniku milczącej zgody przełożonych były $\mathrm{w}$ dokumentacji tak preparowane by uniknąć odpowiedzialności członków personelu [7].

Inne zjawisko, które potencjalnie może powodować generowanie nieprawdziwych danych $\mathrm{w}$ dokumentach urzędowych to tzw drugi obieg informacji. Jeśli zachowania 
negatywne oficjalnie nie występują nieprofesjonalnie postępujący personel jest karany również w sposób nieformalny... [8].

Istnienie nieformalnych interakcji w gronie personelu oraz wśród podwładnych/ osadzonych /powoduje generowanie zjawiska drugiego/sekretnego/ życia instytucji penitencjarnej.

Z aspektu praktycznego oznacza to dla badaczy tej rzeczywistości konieczność zmierzenia się z negatywną solidarnością społeczną, w ramach której każdy podwładny bądż członek personelu może szantażować drugiego.

P. Moczydłowski zwrócił uwagę, że najbardziej narażone na mistyfikację i utrudnianie dostepu do prawdziwych danych są te tematy badań, które są chronione sekretami formalnymi badź nieformalnymi. Dane uzyskiwanie za pomocą stanadardowych metod mają ograniczoną wartość poznawczą, natomiast sprawdza się zastosowanie postawy „naiwnej poznawczo...” [9].

Większość badań prowadzonych w jednostkach penitencjarnych do 1989r. skoncentrowana była na funkcjonowaniu społeczności osadzonych. W latach 90-tych zaczęły się pojawiać publikacje szeroko omawiające zjawisko wypalenia zawodowego personelu więziennego, przystosowania do pracy w warunkach instytucji totalnej. Brak w nich jednak charakterystycznego dla poprzedniego autora zacięcia demaskatorskiego. Przykładem mogą być prace H. Machela i M. Cioska [10,11].

M. Kamiński,w swojej pracy zaproponował zastosowanie postawy obserwującego uczestnika jako bardziej skutecznej i opisując ją opozycyjnie w stosunku do postawy uczestniczącego obserwatora w badaniach nad przejawami drugiego życia instytucji totalnej.

Idealny obserwator-uczestnik według M. Kamińskiego jest:

perfekcyjnie zsocjalizowany do swojej roli, beznamiętnie rejestruje losowo generowane doświadczenia osobiste i przestrzega obowiazujacych lub zmodyfikowanych na potrzeby konkretnego badania norm metodologicznych dotyczacych zbierania danych [8].

Zawodowa wspólnota jak zauważa B. Mikołajewska charakteryzuje się tym, że jej członkowie tworza system wartości, który ma swoje źródła w środowisku zawodowym. System ten oddzialywuje na jednestki ad intra i ad extra. Ograniczenie zakresu przenikliwości tworzy bariery, za którymi dominuje jednorodność stylu życia [9].

Model funkcjonowania jednostki penitencjarnej jako instytucji totalnej zostaje nieświadomie przeniesiony do rzeczywistości rodzinnej i w skrajnych przypadkach może powodować wzrost zachowań związanych ze stosowaniem przemocy fizycznej lub psychicznej. Z uwagi na dobro jakim jest stosunkowo dobrze płatna/ zwłaszcza w rzeczywistości małych miasteczek $\mathrm{i}$ wsi/ praca, o zjawiskach przemocy w rodzinie bardzo rzadko się mówi. Inne zjawisko w rodzinach funkcjonariuszy to tendencje do formalizowania $\mathrm{w}$ interakcjach, nawet $\mathrm{z}$ osobami najbliższymi.

Ponad $50 \%$ kobiet - funkcjonariuszy jest żoną funkcjonariusza więziennictwa lub innej służby mundurowej. Jeśli tak nie jest - żona funkcjonariusza zazwyczaj nie pracuje zawodowo. 


\section{ALTERNATYWNY MODEL BADANIA INSTYTUCJI TOTALNYCH}

W swoich badaniach wykorzystuję możliwość analizowania relacji między stopniem ubezwłasnowolnienia i izolacyjności poszczególnych jednostek penitencjarnych

\begin{tabular}{|c|c|}
\hline $\begin{array}{c}\text { Ubezwlasnowolnienie - cecha podstawowa - } \\
\text { funkcjonowanie w uniwersum przymusu }\end{array}$ & $\begin{array}{c}\text { Izolacyjność - cecha podstawowa - } \\
\text { funkcjonowanie wewnątrz rzeczywistych i } \\
\text { symbolicznych barier }\end{array}$ \\
\hline Podział na personel i podwładnych & $\begin{array}{c}\text { Wszystkie aspekty życia przebiegają w tym } \\
\text { samym miejscu i podlegają jednolitej władzy } \\
\text { zwierzchniej }\end{array}$ \\
\hline $\begin{array}{c}\text { Wszystkie fazy całodziennej działalności są tak } \\
\text { zaplanowane, by jedna przechodziła w drugą, } \\
\text { sekwencje działań narzuca personel }\end{array}$ & $\begin{array}{c}\text { Informacje dotyczące losów członków są często } \\
\text { nieudostępniane }\end{array}$ \\
$\begin{array}{c}\text { Nasilone występowanie negatywnych przejawów } \\
\text { drugiego życia" instytucji }\end{array}$ & $\begin{array}{c}\text { Binarny charakter instytucji wyrażony m.in. w } \\
\text { symbolicznym odizolowaniu ,świata } \\
\text { podwładnych" od ,świata personelu" }\end{array}$ \\
\hline $\begin{array}{c}\text { Każda faza całodziennej działalności jest } \\
\text { realizowana w bezpośredniej obecności innych } \\
\text { osób }\end{array}$ & $\begin{array}{c}\text { Uboczne efekty izolacji: prizonizacja, } \\
\text { hospitalizm, }\end{array}$ \\
\hline $\begin{array}{c}\text { Różze narzucone kierunki działania są } \\
\text { skonstruowany dla realizacji celów instytucji }\end{array}$ & \\
\hline
\end{tabular}

Stopień ubezwłasnowolnienia jest odwrotnie proporcjonalny do wielkości enklawy wolności $\mathrm{w}$ uniwersum przymusu. Im ta enklawa jest mniejsza tym stopień ubezwłasnowolnienia jest większy. Wielkość wspomnianej enklawy można mierzyć w skali jednego dnia poprzez użycie wskaźnika jakim jest ilość czasu wolnego/ do zagospodarowania według własnego uznania przez członków/ pensjonariuszy/ instytucji totalnej, mierzonego w godzinach.

$\mathrm{P} / \mathrm{u} /=1 / \mathrm{W}$

$\mathrm{P} / \mathrm{u} /$ - stopień ubezwłasnowolnienia

$\mathrm{W}$ - wielkość enklawy wolności w uniwersum przymusu.

Gdy wartość $\mathrm{P} / \mathrm{u} /=1$ mamy do czynienia z całkowitym ubezwłasnowolnieniem. 
Stopień izolacyjności jest odwrotnie proporcjonalny do stopnia przepuszczalności. Im ta enklawa jest mniejsza tym stopień izolacyjności jest większy. Wielkość stopnia przepuszczalności można mierzyć w skali jednego dnia poprzez użycie wskaźników jakimi są ilość czasu/mierzonego w godzinach/ w którym:

- członkowie/pensjonariusze/ instytucji totalnej mogą z własnego wyboru przebywać poza nią /przepuszczalność ad extra

- osoby z zewnątrz mogą przebywać na terenie instytucji totalnej kontaktując się z jej członkami/pensjonariuszami /przepuszczalność ad intra/

$\mathrm{P} / \mathrm{i} /=\{1 / \mathrm{oe}+1 / \mathrm{oi}\} / 2$

$\mathrm{P} / \mathrm{i} /$ - stopień izolacyjności

oe - stopień przepuszczalności ad extra

oi - stopień przepuszczalności ad intra

Gdy wartość P/i/ = 1 mamy do czynienia z typem idealnym izolacyjności.

Totalność instytucji- ograniczenie możliwości dokonywania wyborów i podejmowania samodzielnych decyzji, przejęcie kontroli nad czasem i przestrzenią w której funkcjonują podopieczni, zaanektowanie, ubezwłasnowolnienie, realizowane $\mathrm{w}$ warunkach izolacji. Stopień totalności jest średnią arytmetyczną stopnia ubezwłasnowolnienia i stopnia izolacji

$\mathrm{P} / \mathrm{t} /=\{\mathrm{P} / \mathrm{u} /+\mathrm{P} / \mathrm{i} /\} / 2$

$\mathrm{P} / \mathrm{t} /$ - stopień totalności

Gdy wartość P/t/ = 1 mamy do czynienia z typem idealnym instytucji totalnej [14].

Totalność instytucji mierzona jest w kontekście pobytu w nich osób pozbawionych wolności, jednak w dużym stopniu wpływa ona również na powstawanie syndromu wypalenia zawodowego wśród funkcjonariuszy i pracowników cywilnych więziennictwa [14]. Bez zaufania, bez przekonania, że można wierzyć drugiej osobie, nie da się dobrze funkcjonować ani w rodzinie, ani w miejscu pracy, ani w państwie i jego instytucjach. Jak wskazują wyniki najnowszych badań nad zaufaniem, w życiu społecznym Polacy są raczej nieufni. Tylko niespełna jedna czwarta badanych (23\%) wychodzi z założenia, że większości ludzi można ufać, blisko trzy czwarte zaś (74\%) wyznaje zasadę zachowywania daleko idacej ostrożności $w$ stosunkach $z$ innymi [16]. Zasada ta powoduje nieufność wobec instytucji życia publicznego i wszelkie działania które zwiększają izolacyjność instytucji kosztem transparentności są postrzegane negatywnie. Funkcjonowanie instytucji penitencjarnych nieodłącznie wiąże się $\mathrm{z}$ istnieniem szeregu barier fizycznych i formalnych. Życie ,za murami” związane jest z powstawaniem wielu niedopowiedzeń i podejrzeń.

Prowadzenie badań w takim środowisku samo w sobie jest niezwykle skomplikowane począwszy od uzyskania zgody na prowadzenie badań/ niezbędne zaufanie decydentów i odporność na problemy biurokratyczne/, poprzez przygotowanie badań/ niezbędna świadomość szeregu ograniczeń co do metod i technik badawczych/ prowadzenie badań/ pod mniej lub bardziej jawnym nadzorem pracowników instytucji penitencjarnej/ a kończąc na publikacji wyników badań/ próby ukrywania stwierdzonych nieprawidłowości w funkcjonowaniu danej instytucji/. Wszystkie instytucje penitencjarne funkcjonują według zasady, że stanem prawidłowym jest poziom neutralny. Wszystkie czynniki zaburzające 
normalne funkcjonowanie instytucji są klasyfikowane jako negatywne i personel robi wszystko by te czynniki zneutralizować. Takim zaburzeniem z reguły jest równieź obecność osób spoza personelu/ np. wizytacji w ramach nadzoru penitencjarnego, czy prowadzenia badań naukowych/. Pojawienie się osób wizytujących bądź badających funkcjonowanie instytucji $\mathrm{z}$ reguły powoduje minimalne zaufanie personelu i niechęć do udzielania jakichkolwiek informacji. Skutkiem tego często raporty powstające w ramach nadzoru penitencjarnego, czy badania naukowe nie do końca odzwierciedlają rzeczywistość.

\section{WNIOSKI}

Wyjściem z tego „metodologicznego pata” jest prowadzenie badań w dłuższym okresie czasu, który pozwoli personelowi „oswoić się” z pobytem badacza a samemu badaczowi poznać również te niedopowiedziane fakty istotne $\mathrm{z}$ aspektu tematu prowadzonych badań.

\section{References}

[1] Sztompka P., Studia Socjologiczne 4 (147) (1997).

[2] Sztompka P., Socjologia 13 (2002) 316.

[3] Ibid., s. 326.

[4] Goffman.E, Instytucje totalne, Sopot 2011, s. 15-16.

[5] Foucault M.: Nadzór i kara, w: Literatura na świecie 6/88, s. 262-274.

[6] Davies C., Human Studies 12(1-2) (1989) 83.

[7] Moczydłowski P., Drugie życie więzienia, Warszawa 1991, s. 14-15.

[8] Ibid, s. 18.

[9] Ibid, s. 23-30.

[10] Ciosek M., Psychologia sadowa i penitencjarna, Warszawa, 2001.

[11] Machel H., Personel więzienny jako kategoria zawodowa i jako przedmiot zainteresowań badawczych w: Ludzie,instytucje, idee, ( red Iwanek I.) Katowice, 1997.

[12] Kamiński M., Gry więzienne, Warszawa, 2006, s. 22.

[13] Mikołajewska B., Ochronna wspólnota i tożsamość jednostki, w: (red. Machaj I.) Małe struktury społeczne, Lublin 1998, s. 189-190.

[14] Borowski A., Instytucje religijne jako instytucje totalne, w: /red. A. Wójtowicz/ Socjologia Religii ks. W. Piwowarskiego, Warszawa, 2004, s. 133-136.

[15] Piotrowski A., Stres $i$ wypalenie zawodowe funkcjonariuszy Stużby Więziennej, Warszawa 2011.

[16] Cybulska A., Zaufanie społeczne, raport CBOS BS/33/2012, s. 3. 